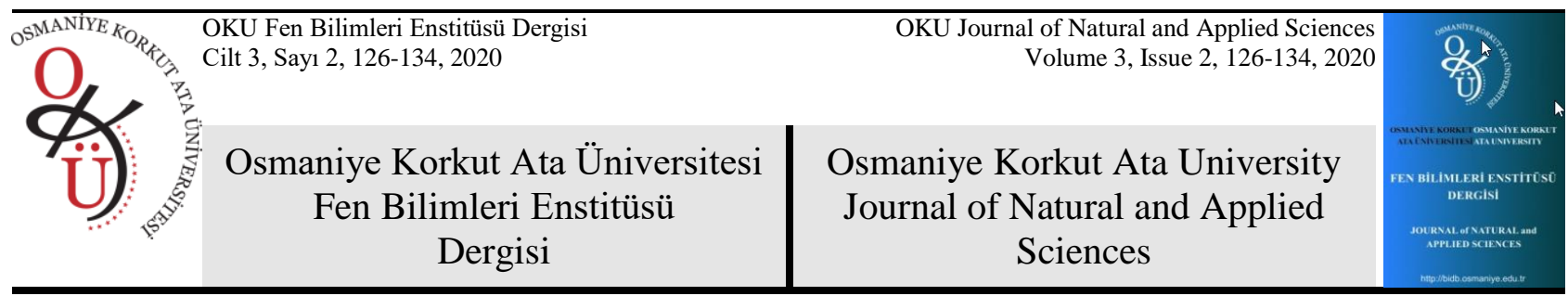

\title{
Parmak Peynirinden İzole Edilen Staphylococcus Türlerinin Virulans Faktörleri ve Antibiyotik Dirençliliği
}

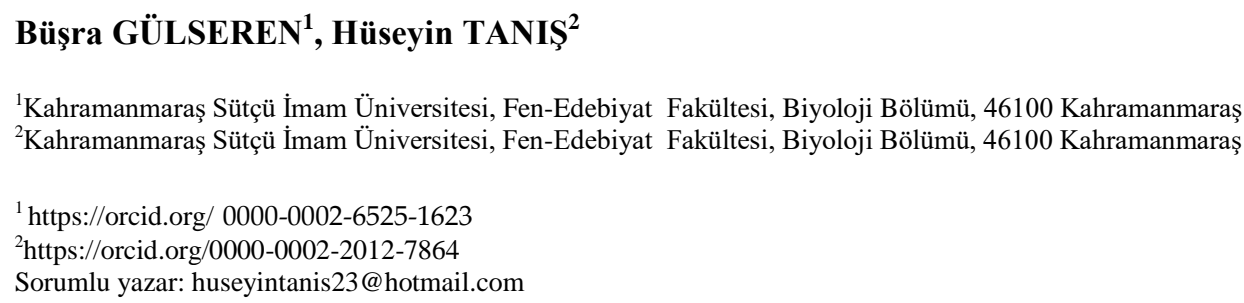

\section{Araştırma Makalesi}

\section{Makale Tarihçesi:}

Geliș tarihi: 26 Eylül 2020

Kabul tarihi:18 Ekim 2020

Online Yayınlanma: 15 Aralık 2020

\section{Anahtar Kelimeler:}

Staphylococccus

Parmak peyniri

Antibiyotik duyarlılığı

\begin{abstract}
ÖZET
Bu araştırma Kahramanmaraş yöresine özgü parmak peynirlerinde Staphylococcus bakterisi incelemesi ve bu bakterilerin virülans faktörleri ve antibiyotik dirençlilik özelliklerinin tespiti amacıyla yapılmıştır. Araştırma kapsamında 30 farklı parmak peynir numunesi incelenmiştir. Bu numunelerden izole edilen 14 suşun tamamının KNS olduğu belirlenmiştir. Araştırma sonucu izole edilen 14 suşun araştırmada kullanılan antibiyotiklerden Nitrofurantoin'e \%100; Gentamicin ve Streptomycin'e $\% 92,8$; Amoxillin, Chlaromphenicol, Erythromycin ve Tetracycline'e \%85,7; Novobiocin'e \%71,4; Cephalothin ve Clindomycin'e \%64,2; Ampicillin'e \%57,1 oranında duyarlılık gösterdiği tespit edilmiştir.
\end{abstract}

\section{Virulence Factors and Antibiotic Resistance of Staphylococcus Species Isolated from Finger Cheese}

\section{Research Article}

\section{Article History:}

Received: 26 September 2020

Accepted: 18 October 2020

Published online: 15 December 2020

\section{Keywords:}

Staphylococcus

Finger cheese

Antibiotic sensitivity \begin{abstract}
The aim of this study was to investigate Staphylococcus bacteria in finger cheese of Kahramanmaraş region and to determine the virulence factors and antibiotic resistance of these bacterias. 30 different finger cheese samples were examined of this study. All 14 strains isolated from these samples were determined to be CNS. As a result of the study, 14 strains isolated from the antibiotics used in the study Nitrofurantoin'e 100\%; Gentamicin and Streptomycin 92,8\%; Amoxillin, Chlaromphenicol, Erythromycin and Tetracycline 85,7\%; Novobiocin 71,4\%; Cephalothin and Clindomycin 64,2\%; Ampicillin was found to be $57,1 \%$ sensitive.
\end{abstract}

To Cite: Gülseren B., Tanış H. Parmak Peynirinden İzole Edilen Staphylococcus Türlerinin Virulans Faktörleri ve Antibiyotik Dirençliliği. Osmaniye Korkut Ata Üniversitesi Fen Bilimleri Enstitüsü Dergisi 2020; 3(2): 126-134.

\section{Giriş}

Sütün peynir olmasındaki en etkili şey bakterilerdir. Süt bakterileri, süt şekeri laktozunu sindirir ve sütü kesmek için eklenen peynir mayas1 ile hareket eden laktik asit üretir. Cheesemaker yani peynir yapicilar peynir altı suyunu süzer ve lorları sıkıştırarak çeşitli mikropların olgun bir peynir haline gelmesini sağlar [1]. Staphylococcus'lar, Micrococcaceae familyası içinde yer alan katalaz pozitif koklardır. Mikroskop altında, küresel yani yuvarlak şekilde görünürler (koklar) ve üzüm benzeri kümeler halinde oluşurlar. 
Aynı zamanda Staphylococcus türleri fakültatif anaerobik organizmalardır (hem aerobik hem de anaerobik olarak üreyebilen). Staphylococcus en az 40 türü tespit edilmiştir [2]. Bunlardan dokuzunun iki alt türü, birinde üç alt türü ve birinde dört alt türü vardır. Çoğu zararsızdır ve normal olarak insan ve diğer organizmaların cilt ve mukoza zarlarında bulunur. Staphylococcus'un nektarda yaşayan bir türü de bulunmuştur. Dünya çapında bulunan toprak mikrobiyal florasının küçük bir bileşenidir [3].

Staphylococcus, bakteriyel gida zehirlenmesi salgınlarında rastlanan ajanlardan biridir. Aynı zamanda, süt evcil ruminantlarının klinik veya subklinik mastitisinin ana nedenlerinden biri olan patojendir [4]. Kanatlı hayvan, et ve yumurta ürünlerinin yanı sıra süt ve süt ürünlerinin de stafilokokal gida zehirlenmesine yol açabilecek yaygın gıdalar olduğu bildirilmiştir [5]. Staphylococcus suşları, bu organizmanın patojenitesine katkıda bulunduğu düşünülen bir dizi protein toksini ve virülans faktörü üretmektedir. Stafilokok enterotoksinler (SE'ler) birçok farklı tipte sinıflandırılmıştır. $\mathrm{Bu}$ enterotoksinler, 1sıya dayanıklıdır ve sindirim enzimlerinin etkisine karşı dirençlidir [6]. Bu enterotoksinlerin en yaygin tipleri, SEE ve SEA'dir. Toksin genlerini taşıyan izolatlar, stafilokokal gida zehirlenmesi salgınlarının $\% 95$ 'inden sorumludur [7]. Kalan stafilokokal gida kaynaklı hastalık salgınları bu nedenle yeni tanımlanmış diğer SE'ler ile ilişkili olabilir. $\mathrm{Bu}$ nedenle, gidada Staphylococcus'un varlığı, potansiyel bir sağlık riski olarak kabul edilebilir [8].

Nispeten spesifik olmayan, hareketsiz bir kokoid bakteri olmasına rağmen, Staphylococcus aureus, hem toplum kökenli hem de hastane enfeksiyonlarında tehlikeli bir insan patojenidir. $\mathrm{Bu}$ bakterinin temel bir biyolojik özelliği, sağl1klı bireyleri asemptomatik olarak kolonileştirme kabiliyetidir. Staphylococcus taşıyıcılarının enfeksiyon riski daha yüksektir ve bireyler arasında yayılan Staphylococcus suşlarının önemli bir kaynağı olduğu varsayılmaktadır [9].

Patojenler, başlıca üç kategoriye ayrılabilen çok çeşitli enfeksiyonlara neden olabilir. Bunlar yara enfeksiyonu gibi yüzeysel lezyonlar, gida zehirlenmesi, haşlanmış cilt sendromu ve toksik şok sendromu gibi toksinler ve üçüncü olarak sistemik ve endokardit, osteomiyelit, zatürree, beyin apseleri, menenjit ve bakteriyemi gibi hayatı tehdit eden durumlardır [10].
Bugün, klinik izolatların yaklaşık \%60'ı MRSA(Metsiline Dirençli Staphylococcus aureus)'dır. Bu, MRSA enfeksiyonlarını tedavi etmek için tercih edilen ilaç olarak vankomisin bırakmıştır. Bununla birlikte, vankomisine karşı orta direnç gösteren Staphylococcus suşları giderek artmaktadır. $\mathrm{Bu}$ enfeksiyonlara sahip hastaların tedavisi mümkün olsa da zordu. Şu anda bu tehlikeli patojene karşı son savunma hattımızı kullandığımızı ve patojenik süreci hakkında ek araştırma yapılması gerektiğini bilinmektedir[11].

Tarihsel olarak, Staphylococcus aureus dünya çapında önemli bir hastalık nedeni olarak kabul edilmiştir ve hem hastane hem de toplum kaynaklı enfeksiyonlarla ilişkili ana patojen olmuştur. Antibiyotiklerin mevcudiyetinden önce, Staphylococcus'un neden olduğu istilac1 enfeksiyonlar genellikle ölümcül olmuştur [12]. Penisilin bulunması ile ağır stafilokok enfeksiyonu olan hastalar için prognozu büyük ölçüde iyileștirdi, ancak birkaç yıllık klinik kullanımdan sonra $\beta$-laktamaz üretimi nedeniyle direnç ortaya çıktı.

Metisilin, $\beta$-laktamaz bozulmasına karşı koyacak şekilde tasarlanmıştır, ancak metisilin klinik uygulamaya konulduktan hemen sonra tüm $\beta$ laktam antibiyotiklere dirençli olan MRSA suşları tanımlandı. Yakın zamana kadar, MRSA baskın olarak hastane kaynaklı enfeksiyonlara neden olan bir nozokomiyal patojendi, ancak MRSA suşları şu anda toplum kaynaklı enfeksiyonlardan giderek daha fazla izole edilmektedir.

Vankomisin, MRSA enfeksiyonlarını tedavi etmek için tercih edilen antibiyotiktir ve son y1llarda bildirilen vankomisin-algilanamayan Staphylococcus'un ortaya çıkması, halk sağlı̆̆ açısından büyük bir endişe kaynağıdır ve MRSA enfeksiyonlarının tedavisini klinisyenler için daha da zorlaştırmaktadır [13].

$\mathrm{Bu}$ çalışmada Kahramanmaraş ilinde geleneksel yöntemlerle üretimi yapılan ve açık bir şekilde satılan yöresel parmak peynirlerindeki insan sağlı̆g 1 için tehlike arz eden Staphylococcus türü bakterilerin tespiti ve bunların antibiyotik dirençlerinin ölçülmesi amacıyla yapılmıştır.

\section{Materyal ve Metot}

\subsection{Parmak Peynirlerinin Temini}

$\mathrm{Bu}$ araştırmada Kahramanmaraş yöresine özgü bir peynir türü olan parmak peynir örnekleri 
kullanılmıştır. Tesadüfü olarak şehrin değişik pazar ve marketlerinden 30 adet parmak peyniri örneklerinden 250'şer gram alınmıştır. Alınan peynir örnekleri steril poşetlere konulmuş ve soğuk zincir altında laboratuvara getirilmiş, buzdolabında $+40{ }^{0} \mathrm{C}$ 'de saklanmış ve 24 saat içinde incelemelere başlanmıştır. Örnekler araştırma sonuna kadar buzdolabı koşullarında saklanmıştır.

\subsection{Staphylococcus 'ların İzolasyonu}

Araştırma kapsamında öncelikle numuneler Mannitol salt agar besiyerine ekilmiştir. Mannitol salt agarda sarı zon oluşturan sarı-parlak kolonilere ve kırmızı-mor zon oluşturan beyaz şüpheli koloniler daha sonra Bair Parker Agar besiyerine ekilmiş ve siyah- kurşuni renk oluşturan kolonilerden suşlar oluşturulmuştur. Daha sonra elde edilen suşlara katalaz, koagüloz, oksidayon fermentasyon testleri yapılmıştır. Bair Parker Agar siyah- kurşuni, katalaz pozitif, koagüloz pozitif ve oksidasyon-fermentasyon testi (O/F Glikoz) pozitif olan koloniler Staphylococcus spp. olarak adlandırılmıştır. Staphylococcus olarak adlandırılan izolataların Nutrient agara pasajları yapılarak stok kültürleri hazırlanmıştır ve $+4^{\circ} \mathrm{C}$ 'de saklanmıştır.

\subsection{Staphylococcus'ların Ayrımında Kullanılan Testler}

\subsubsection{Katalaz testi}

Sıv1 besiyerinde $(5 \mathrm{ml})$ üremiş kültür örnekleri üzerine \%3'lük hidrojen peroksid'den ilave edildi. Hidrojen peroksid ilave edildikten sonra kabarcık oluşumu pozitif reaksiyon olarak kabul edildi [14].

\subsubsection{Koagülaz Testi}

Nutrient Broth'da 24 saat inkübe edilip geliştirilip bakteri içinde $1 \mathrm{ml}$ plazma bulunan tüplere 50 'șer mikrolitre ekildi ve 2 saatlik inkübasyona bırakıldı. İnkübasyon sonunda çökelti oluşturanlar pozitif koagülaz, oluşturmayanlar koagülaz negatif olarak kabul edildi [15].

\subsubsection{Oksidasyon- Fermantasyon Testi}

Besiyeri bileşenlerinin tamamı saf suyla karıştırıldı. Otoklavda $15 \mathrm{dk} 121^{\circ} \mathrm{C}$ de steril edildi. Otoklavdan önce 14 koloni örneğimiz her bir örnekten 2'şer tüp olmak üzere toplamda 28 tüpe 5'er ml olarak dağıtıldı. Otoklavdan steril işleminden sonra tüplere örneklerden ekim yapıld1. Tüplerden 14 tanesi steril parafinle kapatılarak oksijensiz kalması sağlanarak fermantasyona birak1lır. Tüplerin hepsi $37^{\circ} \mathrm{C}$ de 24 saat süreyle inkübasyona bırakı1ır. 14 koloni örneğimizin her birinden bir adet ağzı açık tüpte (oksidasyon için) bir adet de parafinle ağzı kapalı tüpte de sarı renk oluşturanlar pozitif olarak kabul edildi [16].

\subsection{Staphyloccocus'ların Virülans Faktörlerini Belirlemede Yapılan Testler}

\subsubsection{Mannitol Testi}

Brain Heart Broth (merck) besiyerinde 18 saat inkibe edilen izolatlardan mannitol bulunan tüplere $1 \mathrm{ml}$ ilave edildi. $37^{\circ} \mathrm{C}^{\prime}$ de $24-48$ saat inkübasyona bırakıldı. İnkübasyon sonrasında besiyerinde gözlenen renk değişikliğine göre sonuçlar değerlendirildi. Besiyerinde sarı renk değişikliği pozitif olarak kabul edildi [17].

\subsubsection{Pigmentasyon Testi}

Chapman agar 1 litre destile suda çözündükten sonra firında eritilip ardından 15 dakika $121^{\circ} \mathrm{C}$ de otoklavda steril edildi. Besiyerleri (Chapman agar'l1) döküm sicaklığuna geldikten sonra (45$50^{\circ} \mathrm{C}$ ) petrilere 20 'şer $\mathrm{ml}$ olarak döküldü. Agarlı besiyerlerinin katılaşması için beklendi. Her bir örnekten alındıktan sonra petrilere iki defa çizgi ekim yapıld. Besiyerinde sar1-krem renk oluşturanlar pozitif olarak kabul edildi [15].

\subsubsection{Hemoliz Testi}

$100 \mathrm{ml}$ Blood Agar hazırlandı ve otoklavda $121^{\circ} \mathrm{C}$ 'de 15 dakika steril edildi. Döküm sıcaklığındaki (40-45) ağarın içine $1 \mathrm{ml}$ steril kan ilave edildi. Petrilere (5 adet) döktükten sonra katılaşması beklendi. Örnekler her petriye 3 tane, 5. Petriye 2 tane olacak şekilde steril kürdanla saf kültürden alındı (N.A'da sürme ekimle geliştirildi) ve blood ağara ekildi. İnkübasyon için 4 saat süreyle etüve konuldu. İnkübasyon sonucunda hemoliz oluşturanlar pozitif olarak kabul edildi [18].

\subsubsection{DNase Testi}

DNAse agar 1 litre distile suda çözülüp $15 \mathrm{dk}$ $121^{\circ} \mathrm{C}$ de otoklavda steril edildi. Petrilere tüplerden (daha önceden stoğa alınmış) örnekler alındı. DNAse ağara çizgi ekimi yapıldı. 24-48 saat süreyle etüvde inkübasyona birakıldı. Petrilerde gelişme gözlendikten sonra petrilerdeki besiyerlerine (DNAse agar'a) $1 \mathrm{~N} \mathrm{HCl}$ çözeltisi ile kaplandı ve birkaç dakika beklendi. Koloni 
etrafinda berrak zon oluşturanlar pozitif olarak kabul edildi [16].

\subsubsection{Slime Faktör Testi}

$\mathrm{Bu}$ deneyde Brain Heart Broth ve diğer bileşenler saf suda çözündükten sonra mikrodalga firında eritildi (bileşenlerin homojen olarak dağılması için) ve otoklavda $15 \mathrm{dk} 121^{\circ} \mathrm{C}$ de steril edildi. Döküm sıcaklığına geldikten sonra örnek sayısı kadar petrilere döküldü. Daha önceden stoğa alınmış örneklerden alınmış örneklerden petrilere iki defa çizgi ekim yapıldı. Sonra 24-48 saat süreyle inkübasyona (etüvde) bırakıldı. Görmek istenen sonuç bakterilerin (örneklerden alınan kolonilerin siyah koloni oluşturmasıydı ancak hiçbirinde siyah renge rastlanılmadığ faktör oluşumu negatif olarak kabul edildi [19].

\subsection{Antibiyogram Testi}

Saf kültür olarak elde edilen bakteri suşlarının kullanılan antibiyotiklere karşı duyarlılıkları Kirby-Bauher disk difüzyon yöntemi ile saptand. Nutrient Broth da inkübe edilen bakteriler 0.5 MacFarland $(1.5 \times 10 \quad \mathrm{CFU} / \mathrm{ml})$ bulanıklılık standardına göre ayarlandı ve Müeller Hinton Agar petrilerine steril drigalski çubukları ile ekimleri yapıldı. Antibiyotik diskler yerleştirilmeden önce petrilerin kurumas 1 için 10 $\mathrm{dk}$ etüvde bekletildi. Ekim yapılan besiyerine kullanılacak olan antibiyotik diskleri yerleştirildi. 18- 24 saat $37{ }^{\circ} \mathrm{C}^{\prime}$ de inkübe edildikten sonra disklerin etrafinda üreme görülmeyen zonlar ölçülerek hassas veya dirençlidir diye değerlendirmesi yapıldı.

Değerlendirmeler National Committee for Clinical Laboratory Standarts (NCCLS, 1997) standartlarına göre yapılmıştır [20].

\section{Bulgular}

\subsection{Parmak Peynirlerinden İzole Edilen Staphylococcus 'ların Dă̆glımı}

$\mathrm{Bu}$ araştırmada Kahramanmaraş yöresine özgü parmak peynirlerinde Staphylococcus bakterisi incelemesi ve bu bakterilerin virülans faktörleri özelliklerinin ve antibiyotik dirençlilik özellikleri araştırılmıştır. Araştırmada 30 adet farklı parmak peyniri numunesi kullanılmışıtır.

İlk olarak Staphylococcus bakterilerinin tespiti ve Mikrococcus'lardan ayrımının yapılabilmesi için örnekler Mannitol Salt Agar (MSA) besiyerine ekilmiş ve 30 örnekten 26 örnek sarı, pembe ve turuncu renkteki koloniler Staphylococcus olduğu yönünde şüpheli görülerek görülmüştür. 26 örnek ile katalaz ve Oksidayson- Fermentasyon (O/F) testleri yapılmıştır. $\mathrm{Bu}$ testlerde sonucu pozitif çıkan örnekler Baird Parker Agar (BPA) besiyerine ekilmiş ve kaogüloz testi yapılmıştır (Tablo 1).

Tablo 1 incelendiğinde 30 örnekten 26'sında Staphylococcus olduğu yönünde şüphelenilmiş ancak katalaz ve $\mathrm{O} / \mathrm{F}$ testlerine göre 14 örnekte Staphylococcus belirlenerek izole edilmiştir. Daha sonra 14 suş üzerinde Staphylococcus tür tespitine yönelik olarak BPA besiyerine ekim ve kaogüloz testi yapılmıştır. 14 suşta BPA ekimine göre siyah ve kurşuni koloni oluştuğu görülürken koloni çevrelerinde beyaz- parlak bir zon tespit edilememiştir. Kaogüloz testine görede 14 suşun tamamında kaogülüz testinin negatif (KNS) olduğu belirlenmiştir.

İzole edilen 14 suş Staphylococcus'un virülans faktörleri Mannitol Testi, Pigmentasyon Testi, DNase Testi, Hemoliz Testi ve Slime Faktör testi gibi biyokimyasal testler ile belirlenmiştir. Tablo 2 incelendiğinde, Mannitol testi uygulanan suşların tamamında mannitol testinin pozitif olduğu görülmektedir.

Pigmentasyon testi sonuçlarına göre, suşların 7 tanesinde (\%50) pigment oluşumu negatif, 7 tanesinde $(\% 50)$ pozitif olarak bulunmuştur. DNase testi sonuçlarına göre, suşların 5 tanesinde $(\% 35,71)$ pozitif, 9 tanesinde $(\% 64,29)$ pozitif olarak bulunmuştur.

Hemoliz testi sonuçlarına göre, suşların tamamında hemoliz testinin pozitif olduğu görülmektedir.

Slime faktör testi sonuçlarına göre, suşların tamamında slime faktör varlığı negatif olarak bulunmuştur.

\subsection{Staphylococcus Türü Bakterilerin Antibiyotik Duyarlilikları}

Araştırma kapsamında elde edilen Staphylococcus'ların antibiyotik duyarlılıklarının tespit edilebilmesi için antibiyotik zon çapları ölçülmüş ve bu ölçüler NCCLS standartlarına göre dirençlilik özellikleri aşağıda verilen Tablo 3 ve Tablo 4'de verilmiştir. 
Tablo 1. Staphylococcus tespitine yönelik yapılan test sonuçları

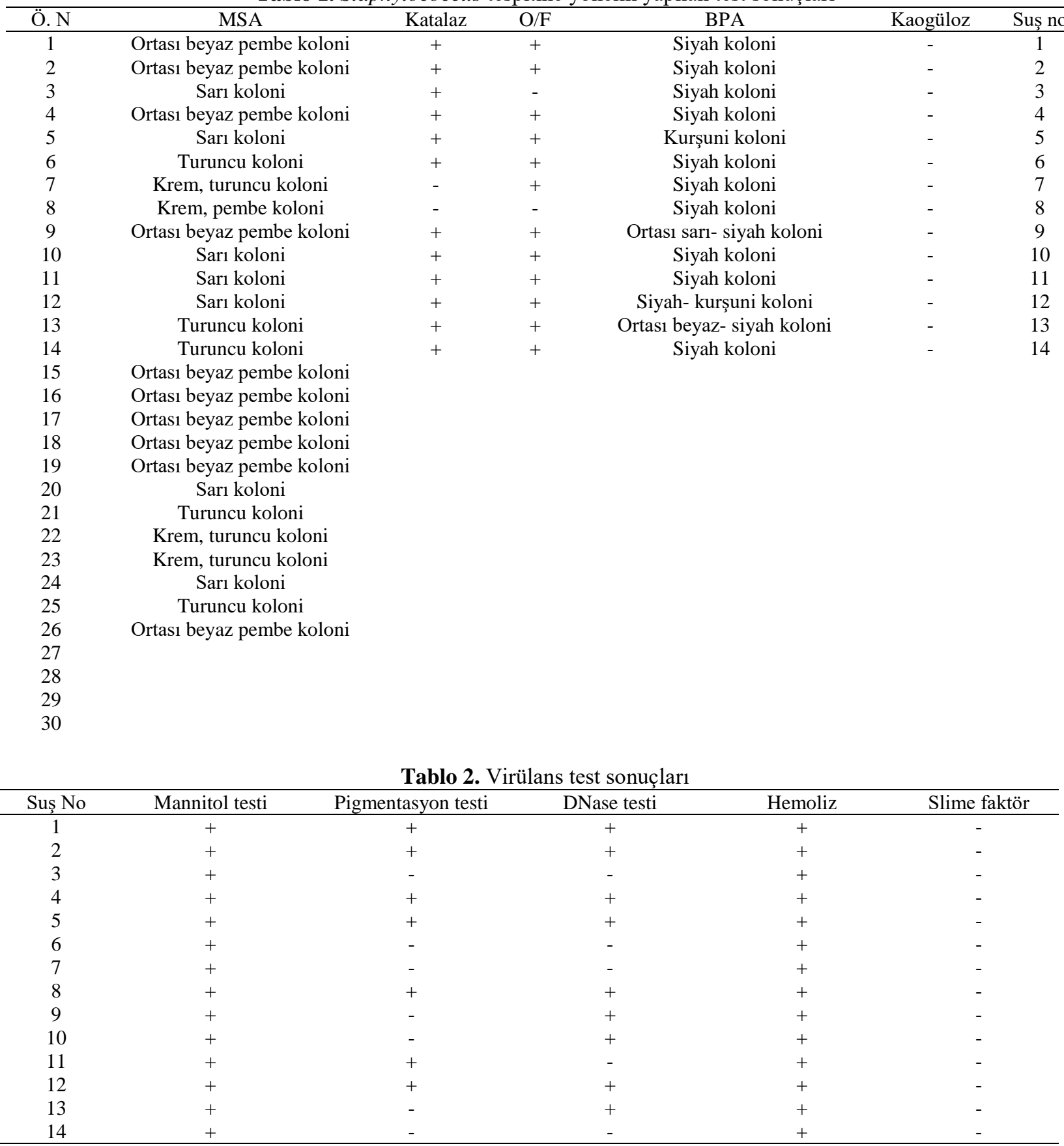

Tablo 3. Staphylococcus 'ların antibiyogram test sonuçları

\begin{tabular}{ccccccccccccccc}
\hline & $\mathbf{1}$ & $\mathbf{2}$ & $\mathbf{3}$ & $\mathbf{4}$ & $\mathbf{5}$ & $\mathbf{6}$ & $\mathbf{7}$ & $\mathbf{8}$ & $\mathbf{9}$ & $\mathbf{1 0}$ & $\mathbf{1 1}$ & $\mathbf{1 2}$ & $\mathbf{1 3}$ & $\mathbf{1 4}$ \\
\hline Amoxillin & 20 & 32 & 30 & 38 & 30 & 32 & 22 & 38 & 0 & 30 & 32 & 32 & 0 & 24 \\
Ampicillin & 36 & 30 & 26 & 30 & 20 & 12 & 0 & 26 & 14 & 8 & 36 & 30 & 0 & 14 \\
Cephalothin & 22 & 20 & 36 & 20 & 38 & 20 & 16 & 20 & 0 & 14 & 20 & 20 & 0 & 0 \\
Chlaromphenicol & 20 & 32 & 20 & 20 & 38 & 20 & 20 & 36 & 0 & 38 & 20 & 32 & 34 & 0 \\
Clindomycin & 30 & 36 & 20 & 30 & 20 & 8 & 0 & 28 & 0 & 0 & 32 & 32 & 30 & 0 \\
Erythromycin & 30 & 30 & 28 & 24 & 32 & 20 & 22 & 28 & 0 & 22 & 28 & 30 & 0 & 20 \\
Gentamicin & 28 & 34 & 34 & 36 & 34 & 20 & 18 & 30 & 0 & 20 & 28 & 28 & 30 & 22 \\
Nitrofurantoin & 36 & 34 & 34 & 36 & 30 & 32 & 34 & 34 & 30 & 30 & 34 & 32 & 24 & 32 \\
Novobiocin & 34 & 22 & 24 & 24 & 26 & 0 & 38 & 34 & 0 & 0 & 30 & 30 & 0 & 26 \\
Streptomycin & 30 & 34 & 36 & 36 & 30 & 20 & 18 & 34 & 0 & 16 & 26 & 30 & 32 & 18 \\
Tetracycline & 20 & 20 & 20 & 22 & 22 & 20 & 20 & 24 & 0 & 20 & 24 & 24 & 0 & 34 \\
\hline
\end{tabular}


Tablo 4. Staphylococcus 'ların antibiyotik duyarlılık özellikleri

\begin{tabular}{|c|c|c|c|c|c|c|c|c|c|c|c|c|c|c|}
\hline & 1 & 2 & 3 & 4 & 5 & 6 & 7 & 8 & 9 & 10 & 11 & 12 & 13 & 14 \\
\hline Amoxillin & $\mathrm{S}$ & $S$ & $S$ & $S$ & $S$ & $\mathrm{~S} * * *$ & $S$ & $S$ & $\mathrm{R}$ & $\mathrm{S}$ & $\mathrm{S}$ & $\mathrm{S}$ & $\mathrm{R}$ & $\mathrm{S}$ \\
\hline Ampicillin & S & S & S & S & S & $\mathrm{I} * *$ & $\mathrm{R}$ & S & I & $\mathrm{R}$ & $\mathrm{S}$ & $\mathrm{S}$ & $\mathrm{R}$ & I \\
\hline Cephalothin & S & S & S & S & S & $\mathrm{S}$ & I & S & $\mathrm{R}$ & I & S & $\mathrm{S}$ & $\mathrm{R}$ & $\mathrm{R}$ \\
\hline Chlaromphenicol & $S$ & S & S & S & S & $\mathrm{S}$ & $S$ & S & $\mathrm{R}$ & $\mathrm{S}$ & S & $\mathrm{S}$ & $\mathrm{S}$ & $\mathrm{R}$ \\
\hline Clindomycin & S & S & S & S & S & $\mathrm{R} *$ & $\mathrm{R}$ & S & $\mathrm{R}$ & $\mathrm{R}$ & S & $\mathrm{S}$ & $\mathrm{S}$ & $\mathrm{R}$ \\
\hline Erythromycin & $S$ & S & S & S & S & $\mathrm{S}$ & S & S & $\mathrm{R}$ & $\mathrm{S}$ & S & $\mathrm{S}$ & $\mathrm{R}$ & $\mathrm{S}$ \\
\hline Gentamicin & S & S & S & S & S & S & S & S & $\mathrm{R}$ & S & S & $\mathrm{S}$ & $\mathrm{S}$ & $\mathrm{S}$ \\
\hline Nitrofurantoin & S & S & S & S & S & $\mathrm{S}$ & S & S & S & $\mathrm{S}$ & S & $\mathrm{S}$ & $\mathrm{S}$ & $\mathrm{S}$ \\
\hline Novobiocin & S & S & $\mathrm{S}$ & $\mathrm{S}$ & $\mathrm{S}$ & $\mathrm{R}$ & $\mathrm{S}$ & $\mathrm{S}$ & $\mathrm{R}$ & $\mathrm{R}$ & $\mathrm{S}$ & $\mathrm{S}$ & $\mathrm{R}$ & $\mathrm{S}$ \\
\hline Streptomycin & S & $\mathrm{S}$ & $\mathrm{S}$ & $\mathrm{S}$ & $\mathrm{S}$ & $\mathrm{S}$ & $\mathrm{S}$ & $\mathrm{S}$ & $\mathrm{R}$ & S & $\mathrm{S}$ & $\mathrm{S}$ & $\mathrm{S}$ & $\mathrm{S}$ \\
\hline Tetracycline & $\mathrm{S}$ & $\mathrm{S}$ & $\mathrm{S}$ & S & S & $\mathrm{S}$ & S & S & $\mathrm{R}$ & $\mathrm{S}$ & $\mathrm{S}$ & $\mathrm{S}$ & $\mathrm{R}$ & $\mathrm{S}$ \\
\hline
\end{tabular}

Tablo 4 incelendiğinde, Nitrofurantoin'e 14 adet suşun hepsinin, Gentamicin ve Streptomycin'e 9 nolu suş hariç hepsinin, Amoxillin, Erythromycin ve Tetracycline'e 9 ve 13 nolu suşlar hariç hepsinin, Chlaromphenicol'a 9 ve 14 nolu suş hariç hepsinin, Novobiocin'e 6, 9, 10 ve 13 nolu suşlar hariç hepsinin duyarlılık gösterdikleri tespit edilmiştir. Ayrıca Ampicillin'e 6, 9 ve 14 nolu suşlar duyarlılık gösterirken 10 nolu suşun hassas olduğu, 7 ve 13 nolu suşların dirençlilik diğerlerinin ise duyarlılık gösterdiği tespit edilmiştir. Cephalothin'e 7 ve 19 nolu suşların hassasiyet gösterirken 9,13 ve 14 nolu suşların direnç ve diğerlerinin duyarlılık gösterdiği gözlenmiștir. Clindomycin'e 6, 7, 9, 10 ve 14 nolu nolu suşların dirençlilik diğer suşların duyarlılık gösterdiği tespit edilmiştir.

$\mathrm{Bu}$ sonuçlara göre, suşların Nitrofurantoin'e $\% 100$; Gentamicin ve Streptomycin'e \%92,8; Amoxillin, Chlaromphenicol, Erythromycin ve Tetracycline'e \%85,7; Novobiocin'e \%71,4; Cephalothin ve Clindomycin'e \%64,2; Ampicillin'e \%57,1 oranında duyarlılık gösterdiği tespit edilmiştir.

\section{Tartışma ve Sonuç}

Süt ve süt ürünleri insan beslenmesi için önemli besin kaynakları oldukları kadar hijyen koşullarına uyulmadığı takdirde insan sağlığını tehlikeye atabilecek zararlı mikroorganizmaların ve bakterileri bünyesinde barındıran besinler haline gelmektedir. Özellikle standartlara uygun işletmelerde üretimi yapılmayan ve açıkta satılan süt ve süt ürünleri dikkatli davranılması gerekmektedir. Çünkü Staphylococcus 'ların insan sağlığına etkisinin belirlenmesi açısından Staphylococcus 'larm tespiti kadar bu bakterilerin antibiyotik türlerine karşı geliştirmiş oldukları dirençlilikte önemli bir faktördür.

$\mathrm{Bu}$ araştırma kapsamında farklı yerlerden alınan 30 parmak peynir numunesi incelenmiştir. $\mathrm{Bu}$ numuneler içerisinde ilk aşamada 26 tanesinin Staphylococcus olduğundan şüphelenilmiş ve katalaz ve $\mathrm{O} / \mathrm{F}$ testlerine göre 14 örnekte Staphylococcus belirlenerek izole edilmiştir. Daha sonra 14 suş üzerinde Staphylococcus tür tespitine yönelik olarak BPA besiyerine ekim ve kaogüloz testi yapılmıştır. 14 suşta BPA ekimine göre siyah ve kurşuni koloni oluştuğu görülürken koloni çevrelerinde beyaz- parlak bir zon tespit edilememiştir. Kaogüloz testine görede 14 suşun tamamının KNS olduğu belirlenmiştir.

$\mathrm{Bu}$ alanda yapılan araştırmalar fermente süt ve süt ürünlerinde KNS türlerine sıklıkla rastlandığını ortaya koymaktadır [21-26]. Hadimli ve ark. [23] mastitisli 651 süt örneğinin 286'sından $(\% 43,9)$ suş izole ederken bunların tamamının, Gillespie ve ark. [22]'nın inceledikleri 412 örnekten 1407 adet suş izole etmiş ve tamamının, Sawant ve ark. [25]'nın çiğ süt numunelerinden izole ettikleri 168 suşların tamamının, Bayar [27], 221 subklinik mastitis süt numunesinden 100 adet Stafilokok izole etmiş ve tüm suşların KNS tespit etmiştir. Yapılan araştırmalarda bulunan sonuçlar bu araştırmada elde edilen sonuçlarla uyuşmaktadır.

İzole edilen stafilokokların virülans özelliklerin tespit etmeye yönelik yapılan mannitol testine göre 14 suşun tamamı mannitolü fermente ettiği tespit edilmiştir. $\mathrm{Bu}$ alanda yapılan araştırmalarda farkl1 sonuçlar tespit edilmiştir. Nitekim Boynukara [28], insan ve sığırlar üzerine yaptığı bir çalışmada izole ettiği 50 adet $S$. aureus suşunun tamamının, Gülhan [29], mastitisli ineklerden izole ettiği $S$. aureus suşlarının tamamının, Kireçci [30], klinik ve subklinik mastitisli inek sütlerinden izole ettiği $208 S$. aureus suşunun tamamının, Turan [31], süt ve süt ürünlerinden $110 \mathrm{~S}$. aureus izolatının tamamının mannitolü fermente ettiğini ve Duman [32] izole ettiği $118 \quad S$. aureus'un $114 \quad(\% 96,6)$ 'sının mannitolü pozitif, $4(\% 4,3)$ 'ü negatif, 222 KNS'nin $171(\% 77,0)$ 'inin mannitolü pozitif, 51 (\%51)'i de negatif olarak tespit etmiştir. 
Virülans özelliklerin tespiti kapsamında yapılan pigmentasyon testi sonucunda 14 suşun yarısında negatif (beyaz) yarısında pozitif (sarı) pigment oluşumu tespit edilmiştir. Gülhan [29], yaptığ çalışmada, sığır orjinli $50 \mathrm{~S}$. aureus izolatının 15'inin (\%30) sar1, 35'inin (\%70) beyaz, Boynukara [28], sığır orjinli 50 S. aureus suşunun pigmentasyon testinde \%30'unu sar1, \%70'ini beyaz pigment, Duman [32] 222 KNS'nin 110 (\%49,5)'unda pozitif, $114 \quad(\% 51,3)$ 'ünde de negatif olarak tespit etmeleri bu araştırmada elde edilen sonuçlarla uyuşmaktadır.

DNase testi sonuçlarına göre, suşların 5 tanesinde (\%35,71) pozitif, 9 tanesinde $(\% 64,29)$ pozitif olarak bulunmuştur. $\mathrm{Bu}$ alanda yapılmış çalışmalarda birbirinden farklı sonuçların bulunduğu dikkat çekmektedir. Nitekim Boynukara [28] 50 adet $S$. aureus suşunun \%98'inde; Gülhan [29] sığır orjinli 50 S. aureus izolatının 48 (\%96)'sında, Kireçci [30], subklinik mastitisli inek sütlerinden izole ettiği $208 \mathrm{~S}$. aureus suşunun $\% 98,5$ 'inde, Turan [31], süt ve süt ürünlerinden izole ettiği $110 \mathrm{~S}$. aureus izolatının tamamında DNase pozitif olarak bulmuşlardır. Buna karşın Türkyılmaz ve Kaya [33], izole ettikleri 53 S. aureus suşunun \%42,2'sinde, Bedini-Madini ve ark. [34] izole ettikleri 165 KNS'den 109'unda DNase pozitif, Duman [32] izole ettiği $222 \mathrm{KNS}$ suşunun $110(\% 49,5)$ 'unda pozitif, $114(\% 51,3)$ 'ünde de negatif pigment oluşumunu tespit etmiştir.

Araştırmamızda 14 izolatın tamamının KNS olarak belirlenmesine rağmen hemoliz testi pozitif olarak bulunmuştur. Hemoliz testi pozitif olan suşların koagulaz pozitif olması gerektiğini ileri süren araştırmalar olduğu gibi KNS'lerinde hemoliz pozitif olabileceğini ileri süren çalışmalar bulunmaktadır [35]. Nitekim Duman [32] 118 S. aureus izolatının tamamında hemoliz testi pozitif, 222 KNS izolatında hemoliz testi $128(\% 57,6)^{\prime} i$ pozitif, 96 (\%43,2)'s1 negatif olarak, Gülhan [29], mastitisli inek sütlerinden izole ettiği $50 \mathrm{~S}$. aureus suşunun tamamının, Boynukara [28] sığır orjinli 50 S.aureus suşunun tamamının, Kireçci [30], klinik ve subklinik mastitisli inek sütlerinden izole ettiği 208 S. aureus suşunun \%85'inin ve Türky1lmaz ve Kaya [33], izole ettikleri $53 \mathrm{~S}$. aureus suşunun \%58,9'unun hemoliz oluşturduğunu tespit etmiştir.

Slime faktör testi sonuçlarına göre, suşların tamamında slime faktör varlığı negatif olarak bulunmuştur. $\mathrm{Bu}$ alanda yapilmış araştırmalarda farklı sonuçlar elde edildiği göze çarpmaktadır. Nitekim Kireçci [30], klinik ve subklinik mastitisli inek sütlerinden izole ettiği 208 S. aureus suşunun $\% 6,25$ 'inde, Turan [31], süt ve süt ürünlerinden izole ettiği $110 \mathrm{~S}$. aureus izolatının $\% 52,7$ 'sinde, Türky1lmaz ve Kaya [33] 180 adet Staphylococcus'un \%61,1'inde slime faktör pozitif olarak tespit etmişlerdir. Duman [32] 118 S. aureus izolatında $114(\% 96,6)$ 'ünde pozitif, 4 $(\% 3,3)$ 'ünde negatif, $222 \mathrm{KNS}$ izolatında 191 $(\% 86,0)$ 'inde pozitif, $31 \quad(\% 13,9)$ 'inde negatif olarak bulmuştur.

Araştırma sonucu izole edilen 14 suşun araştırmada kullanılan antibiyotiklerden Nitrofurantoin'e \%100; Gentamicin ve Streptomycin'e $\quad \% 92,8$; Amoxillin, Chlaromphenicol, Erythromycin ve Tetracycline'e $\% 85,7$; Novobiocin'e \%71,4; Cephalothin ve Clindomycin'e \%64,2; Ampicillin'e \%57,1 oranında duyarlılık gösterdiği tespit edilmiştir. Benzer bir çalışmada Yücel ve Anıl [26], çiğ sütten izole edilen KPS izolatlarının en fazla ampisilin \%62,4 ve penisiline \%47,0, KNS izolatları da metisilin ve penisiline \%39,0 dirençli olduğunu, peynirden izole edilen KNS izolatları ampisiline \%42,8; metisilin, penisilin ve eritromisine ise $\% 28,5$ dirençli olduğunu tespit etmişlerdir.

Bayar [27] 100 adet KNS izolatının Oleandomycin (\%65), Kanamycin (\%66), Erythromycin (\%81), Tetracycline (\%86), Neomycin (\%80), Clindamycin (\%86), Chloramphenicol (\%98) ve Streptomycin (\%80) oranında dirençlilik gösterdiğini tespit etmiştir.

Uçan [36], süt örneklerinden izole ettiği 67 KNS'nin 52 (\%78) adedi ampisiline, 17 (\%25) adedi oksitetrasikline, $7 \quad(\% 10)$ adedi sefaperazona, 55 (\%82) adedi kloksasiline, 10 (\%15) adedi danofloksasine ve $10(\% 15)$ adedi de enrofloksasine dirençli, $1 \quad(\% 1,5)$ adet suş oksitetrasikline, $11(\% 16)$ adet suş enrofloksasine ve $8(\% 12)$ adet suş da danofloksasine orta derecede duyarl1, \%32,1'inin ampisilin'e, $\% 29,2$ 'sinin tetrasiklin'e, \%21,1'inin eritromisin'e, \%19,1'inin metisilin'e, \%7,7'sinin amikasin'e, $\% 7,7$ 'sinin kloromfenikol'e, $\% 6,7$ 'sinin gentamisin'e ve \%4,8'inin klindamisin'e dirençli olduğunu tespit etmiştir [36].

Hadimli ve ark. [23], 286 KNS'nin kloksasiline, enrofloksasine, marbofloksasine, danofloksasine, trimetoprim+sulfametaksazol, ulbaktam+ampisilin ve eritromisine, gentamisine, oksasiline, neomisine, oksitetrasikline ve amoksisilin+klavulanik asite büyük oranda duyarlı 
olduklarını tespit etmiştir. Ektik [37], süt ve süt ürünlerinden izole ettiği $3 \mathrm{KNS}$ suşun tamamının ampisilin, penisilin, sülfametoksazol-trimetoprim, sefoksitin ve oksasiline dirençli olduğunu bulmuştur [37].

Sonuç olarak bu araştırmada 30 parmak peyniri numunesinden 14 stafilokok izole edilirken bunların tamamının KNS olduğu belirlenmiştir. KNS'ler, süt hayvanında mastitislere ve tekrarlayan enfeksiyonlara, süt kalitesini düşürmeye ve verimini azaltmaya sebep olmaktadır. Ayrıca KNS'ler insanlarda da sıklıkla görülen ve antibiyotik direnci gittikçe artmaktadır. $\mathrm{Bu}$ bağlamda hayvan ve insan sağlığ 1 için ciddi bir tehlike oluşturan KNS'ler üzerinde de durulmalı ve gerek gida üretimin de gerekse genel hijyen kurallarına uyulması gerekmektedir.

\section{KAYNAKLAR}

[1] Karabıyıklı ŞE. Peynir üretiminde mikroorganizmaların rolü ve önemli mikroorganizma gruplar1, Journal of New Results in Engineering and Natural Science 2019; 1 : 35-45.

[2] Madigan M., Martinko J. (eds). Brock biology of microorganisms (11th ed.). Prentice Hall. ISBN 978-0-13-144329-7 2005.

[3] Foster T. Staphylococcus, Medical microbiology. 4th edition, Ed. Baron S., University of Texas Medical Branch at Galveston 1996.

[4] Topçu AW., Söyletir G., Doğanay M. İnfeksiyon hastalıkları ve mikrobiyolojisi, Nobel Tip Kitabevleri, İstanbul. 2002.

[5] Le Loir Y., Baron F., Guatier M. Staphylococcus aureus and food poisoning, Genetics and Molecular Research 2003; 2: 6376.

[6] Götz F. Micro Review Staphylococcus and biofilms, Molecular Microbiology 2002; 43(6): 1367-1378

[7] Eker FY., Bostan K. Determination of growth and toxin production potential of Staphylococcus aureus and Clostridium perfringens during döner production process, Turkish Journal of Veterinary and Animal Sciences 2019; 43: 10-22.

[8] Adwan G., Abu-Shanab B., Adwan K. Enterotoxigenic Staphylococcus aureus in raw milk in the north of palestine, Turkish Journal of Biology 2005; 29: 229-232.

[9] Chambers HF., DeLeo FR. Waves of resistance: Staphylococcus aureus in the antibiotic era, Nature Reviews Microbiology 2009; 7(9): 629-641.

[10] Bedini-Madani N., Greenland T., Richard Y. Exoprotein and slime production by coagulasenegative Staphylococci isolated from goats milk, Veterinary Microbiology 1998; 59: 139145.

[11] Honeyman Allen L., Friedman H., Bendinelli Mauro. Staphylococcus aureus infection and disease, Kluwer Academic Publishers, New York, Boston, Dordrecht, London, Moscow, 2002 Print ISBN: 0-306-46591-4

[12] Nazik S., Cingöz E., Şahin AR., Güler S. Kan kültürlerinden izole edilen Staphylococcus aureus suşlarında metisilin direncinin y1llara göre değişimi, Kocaeli Medical Journal 2018; 7(1): 32-36.

[13] Palavecino E. Clinical, Epidemiological, and laboratory aspects of methicillin-resistant Staphylococcus aureus (MRSA) Infections, Methods in Molecular Biology: MRSA Protocols Edited by: Y. Ji, Humana Press Inc. Totowa, NJ. 2007.

[14] Sonnenwirth AC., Jaret L. Granwohl's clinical laboratory methods and diagnosis", C.V. Mosby Company, 8. Edition, 1980. 1629-1637.

[15] http://www.mikrobiyoloji.org/TR/Genel/ BelgeKardes.aspx?F6E10F8892433CFFA79 D6F5E6C1B43FF3DB31F6A1D609AA7

[16] Faller D., Schleifer KH. Modifiedoxidase and benzidine test for separation of staphylococci and micrococci, Journal of Clinical Microbiology 1981; 13(6): 1031-1035.

[17] Koneman MD., Aillen SD., Schreckenberger PC., Janda WM., Winn WC. Diagnostic microbiology, J.B. Lippincott Company, 1992 423-425, 435-466.

[18] Tham T., Hadju LJ. A comparison of six media isolation $S$. aureus from foods, Food Microbiol 1997; 4: 133-146.

[19] Freeman DJ., Falkiner FR., Keane CT. New method for detecting slime producing by coagulase negative staphylococci, Journal of Clinical Pathology 1989; 42: 872-874.

[20] National Committee for Clinical Laboratory Standarts (NCCLS). Methods for dilution antimicrobial susceptibility testing for bacteria that grow aerobically. Approved standart M7-A4, Wayne PA, National Committee for Clinical Laboratory Standarts. 1997.

[21] Cengiz SA., Uraz G. Çiğ sütten izole edilen stafilokokların sefalosporinlere ve karbapenemlere karşı duyarlılıklarının araştırılması, Van Tıp Dergisi 2001; 8(2): 4346. 
[22] Gillespie BE., Headrick SI., Boonyayatra S., Oliver SP. Prevalence of coagulase-negative Staphylococcus species from three dairy research herds, Veterinary Microbiology 2009; 134: 65-72.

[23] Hadimli HH., Pınarkara Y., Sakmanoğlu A., Sayın Z., Erganis O., Uslu A., Al-Shattrawi HJ. Serotypes of Salmonella isolated from feces of cattle, buffalo and camel and sensitivities to antibiotics in Turkey, The Turkish Journal of Veterinary and Animal Sciences 2017; 41: 193-198

[24] Irlinger F. Safety assessment of dairy microorganisms: coagulase-negative staphylococci, International Journal Of Food Microbiology 2008; 126(3): 302-310.

[25] Sawant A., Gillespie B., Oliver S. Antimicrobial susceptibility of coagulasenegative Staphylococcus species isolated from bovine milk, Veterinary Microbiology, 2009; 134(1): 73-81.

[26] Yücel N., Anıl Y. Çiğ süt ve peynir örneklerinden Staphylococcus aureus ve koagülaz negatif stafilokokların identifikasyonu ve antibiyotik duyarlılığı, Türk Hijyen ve Deneysel Biyoloji Dergisi 2011; 68(2): 73- 78.

[27] Bayar S. Süt örneklerinden Staphylococcus ve streptococcus türlerinin izolasyonu, identifikasyonu ve antibiyotik dirençlerinin belirlenmesi. Yüksek Lisans Tezi, Kahramanmaraş Sütçü İmam Üniversitesi Fen Bilimleri Enstitüsü, 2007. Kahramanmaraş.

[28] Boynukara B., Gürtürk K., Gülhan T., Ekin İH., Öğün E. Comparison of latex agglutination test with protein a, clumping factor and coagulase tests for identification of staphylococci isolated from avian, Eastern Journal Of Medicine 1999; 4: 58-60,

[29] Gülhan $T$. İnsan ve sığır orjinli Staphylococcus aureus suşlarının çeşitli biyokimyasal özellikleri ile antibiyotiklere duyarlılıklarının karşılaştırılması, Yüksek Lisans Tezi, Yüzüncü Y1l Üniversitesi Sağlık Bilimleri Enstitüsü, 1998. Van.
[30] Kireçci E. Erzurum yöresinde klinik ve subklinik mastitisli inek sütlerinden izole edilen Staphylococcus türlerinin tanımlanmas1, patojenite testleri, betalaktamaz aktiviteleri ve antibiyotik duyarlılıkları, Doktora Tezi, Atatürk Üniversitesi Sağlık Bilimleri Enstitisü, 2004. Erzurum.

[31] Turan E. Süt ve süt ürünlerinden izole edilen Staphylococcus aureus'ların çeșitli biyokimyasal özellikleri ve antibiyotiklere duyarlılıklarının araştırılması, Yüksek Lisans Tezi, Gazi Üniversitesi Fen Bilimleri Enstitüsü, 2005. Ankara.

[32] Duman T. Tavuk karkaslarından izole edilen Staphylococcus'ların virulans faktörleri ve antibiyotik dirençliliği, Yüksek lisans Tezi Gazi Üniversitesi Fen Bilimleri Enstitüsü 2007. Ankara.

[33] Türkyılmaz S., Kaya O. Determination of some virulence factors in Staphylococcus spp. isolated from various clinical samples, The Turkish Journal of Veterinary and Animal Sciences 2006; 30: 127-132.

[34] Bedini-Madani N., Greenland T., Richard Y. Exoprotein and slime production by coagulase negative Staphylococci isolated from goat milk, Veterinary Microbiology 1998; 59: 139-145.

[35] Gemmel CG. Coagulase-negative staphylococci, Journal of Medical Microbiology 1966; 22: 285-295.

[36] Uçan N. Subklinik mastitisli keçilerdeki koagulaz negatif stafilokokların saptanması ve antibiyotik dirençliliklerinin belirlenmesi, Yüksek Lisans Tezi, Adnan Menderes Üniversitesi Sağlık Bilimleri Enstitüsü, 2014. Aydin.

[37] Ektik N. Balıkesir ilinde süt ve süt ürünlerindeki metisilin dirençli Staphylococcus Aureus'un prevalans1 ve antibiyotik dirençliliği, Yüksek Lisans Tezi, Balıkesir Üniversitesi Sağlık Bilimleri Enstitüsü, $2015 . \quad$ Balıkesir. 